\section{T H E S E S,}

\section{DISSERTATIONI DANICE DE NOTIONE IRONIA}

A. NNEXA

nus

A) JURA MAGISTRI ARTIUM

IN UNIVERSITATE HAFNIENSI RITE OBTINENDA

die sẹtemts.

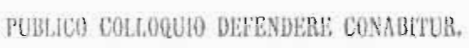

Severimus Aabye Kierkegarol, theot. cant.

MDCCCLXI.

\section{Sin: \\ Segrebet Jurni}

með ftarigt fyenfyn til. Socrates.

Hloginet for Magiffergrabeat

uf

5. श. Sictegant,

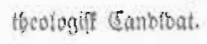

Gajoberbavis.

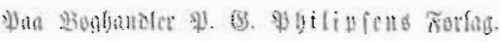
Irytt i Bialleo Qunos Bogtrimfteri.

1841.

Figure 1. On the Concept of Irony.

Kierkegaard's disseratation for a Master's degree, University of Copenhagen, 1841. By special dispensation from the King, Kierkegaard was permitted to submit the thesis in Danish rather than in Latin. Only the title page is in both Latin and Danish.

(Malantschuk-Kierkegaard Collection. Department of Rare Books and Special Collections) 


\title{
A Danish Collection at McGill
}

\author{
By Hans Möller \\ Research and Development Librarian
}

McGill Library Collections include many unique and special collections rich in early materials not found elsewhere. In fact, the collections, are among the oldest in Canada. While ours is no longer the biggest book collection in Canada, it does have depth since it was started back in the 19th century. McGill has outstanding collections in biology and ornithology, art and architecture, Islamic studies, the history of medicine, British history and government documents, and it also supports a fine rare book collection. These are only some of McGill's unique collections of great quality.

The richness of these collections is easily overlooked in the daily struggle to accommodate budget restrictions, deal with the rising cost of books and sift through the proliferation of printed materials from all over the world. One interesting and. little known collection at McGill is that of Scandinavian literature, in particular Danish literature. Although not large, it is significant even though McGill has no Department of Scandinavian Studies. However, the study of Scandinavian culture is included as a part of study and research in many faculties, such as Arts, Music, Medicine, Education, Law, Architecture and Science. The Scandinavian material in these areas are collected in both English and French and in the Scandinavian languages as well, since most scholars who have an interest in Nordic topics know enough of the languages to orient themselves when consulting this literature. The fact is that publications from Denmark, Norway, Sweden, Finland and Iceland are numerous and typically of very high quality. It has been said for instance, that in. Finland and. Iceland almost everybody with respect for him-or herself has written and published a book of poetry! Literacy in all Scandinavian countries is very high and the publication of books is simply staggering considering the modest size of these countries.

During the last 15 years McGill's Department of German Studies has been offering courses in the learning of the Danish language. As a result more and more students have a knowledge of Danish. This goes hand in hand with new efforts to enrich the Scandinavian. library collections, especially the Danish collections, in the humanities and social sciences fields. Traditionally, McGill concentrated its collections development in English translations of Ibsen, Strindberg, Kierkegaard and a few other major authors. Other authors were only collected at random and hardly ever in any of the five Scandinavian languages. Topics such as linguistics, architecture, fine arts and history were very poorly represented. This changed dramatically during the 1980's and 1990's. Many works are now acquired in Swedish, Norwegian and especially Danish. In fact, the Scandinavian collections are now quite respectable and, probably, the best in Canada.

The unique Kierkegaard Collection acquired in 1980 from Dr. Gregor Malantschuk, a Kierkegaard expert in Copenhagen, was a major acquisition. This is a remarkable collection of first editions of all Kierkegaard's works published during his lifetime (Fig, 1) in addition to a complete reconstruction of his private library of books in exactly the very editions he owned himself at the time of his death 1855 . Over 20 of these are in fact the original copies from his library with his own signature or dedications to him from the authors. A detailed analysis of this McGill collection remains to be done. The Malantschuk-Kierkegaard Collection with its 1000 volumes represents one of the best and most valuable in the world outside of Denmark. A printed catalogue has been published and is still available from the Office of the Director of Libraries.

The collection of Danish literature classics has been greatly enriched during the last 15 years with the addition of hundreds of titles by authors such as Ludvig Holberg (1684-1754), Hans Christian Andersen (1805-1875), Georg Brandes ( 1842-1927), Herman Bang (1857-1912), Johannes V. Jensen (1873-1950), Karen Blixen, (alias Isak Dinesen) (1885-1962), Piet Hein (Gruk) (1905-1996), Benny Andersen (1929-

), Peter Høegh and many 


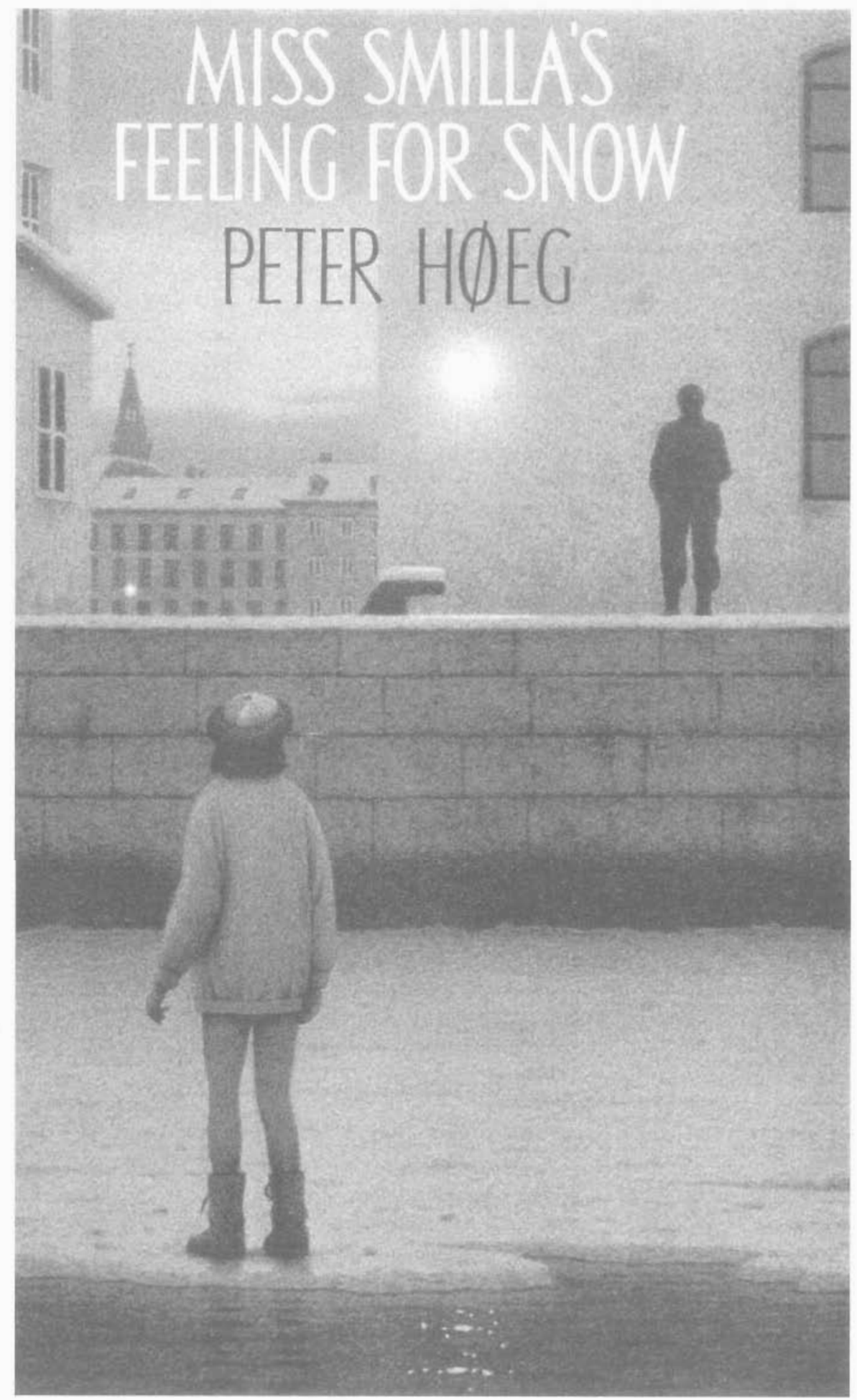

Figure 2. Cover illustration by Quint Buchholtz. A best-seller translated into several languages. 
contemporary novelists and poets (Fig. 2). The McLennan collection also contains numerous editions of Ludwig Holberg, father of Norwegian and Danish literature, including the four-volume Holberg Dictionary. Hans Christian Andersen, is collected extensively in several editions including the recently acquired, complete and critical edition of his Eventyr in seven volumes.

Old Norse literature including the Older and Younger Edda as well as the famous Icelandic Fanily Sagas are well represented in both scholarly and popular editions. A remarkable item within this collection is the complete full-size photo reproduction in folio of the unique Icelandic medieval manuscripts, Corpus Codicum Islandicorum Mediiaevi (20 volumes) published in Copenhagen from 1930 to 1956 by Einar Munksgaard. These are kept in the Department of Rare Books and Special Collections while three additional editions are held in the McLennan open stacks.

Major works on the History of Scandinavian Literature by well-known contemporary scholars such as F. Billeskov Jansen, P.M. Mitchell, Erik Dal and Svend Rossel are kept in the McLennan Library. Works on art and architecture are found in the Blackader-Lauterman Library of Architecture and Art. Among these are Trap Kongeriget Danmark (10 volumes), a complete topographical description of Denmark (1920), and Danske Slotte og Herregaarde (Castles and Manor Houses in Denmark) (20 volumes) by Aage Roussell.

Major Danish reference works are now part of the McGill collections, namely Ordbog over det Danske Sprog (28 volumes), a scholarly dictionary of the Danish Language Det Danske Sprogs Historie (History of the Danish Language) (4 volumes) by Peter Skantrup, Dansk Biografisk Leksikon (16 volumes) a dictionary of Danish biography. These reference works are complemented by the annual Danish Who's Who, Kraks Blå Bog, and several specialized Danish bibliographies. These titles are found in the McLennan Reference collection of the McLennan Library. Of historical interest are complete sets of late 19th century Danish encyclopedias and general reference works, in addition to multi-volume works dealing with inventions and technology from the turn of the century. Other materials may be found in the collections of other McGill libraries, especially those within the subject areas of music, marine biology, glaciology, geology (notably related to Greenland and the Arctic), and the health sciences.

One special collection, recently donated to the Department of Rare Books and Special Collections, concentrates on the Danish Resistance during World War II including the 1943 Rescue of Danish Jews, a topic now much discussed and researched by social scientists in Canada and the USA. This collection also includes samples of underground illegal newspapers distributed during the Nazi occupation of Denmark. (1940-45) as well as books and photographs.

Another unique acquisition, that of silverware crafted by Danish craftsman Carl Poul Petersen, is described in the above note by Conrad Graham.

The Danish collection is housed in several libraries and is not concentrated in one location. Consequently, it serves students and scholars in diverse faculties, not only the Scandinavian Studies courses given by the Department of German. A solid foundation has been secured. Most recent materials have been acquired through generous donations rather than from the McGill book budget. Such donations have come from the Royal Library in Copenhagen, the Royal Danish Embassy in Ottawa and from many generous individuals and Danish family estates in Canada.

\section{Notes}

1. Catalogue of the Gregor Malantschuk-Soren Kierkegaard Collection in the Department of Rare Books and Special Collections. Montreal: McGill University Libraries, 1984. 112 pp. 